\title{
REARING RAINBOW TROUT JUVENILE FISH OF THIS YEAR AT DIFFERENT LEVELS OF PROTEIN IN FEED STUFFS
}

\author{
V. M. KONDRATIUK, PhD in Agriculture, \\ Associate Professor of P.D. Pshenychnyi Animal Feeding and Feed Technology \\ Department, \\ https://orcid.org/0000-0002-4246-2639 \\ E-mail: vadkondratyk@ukr.net \\ National University of Life and Environmental Sciences of Ukraine
}

\begin{abstract}
The article considers the efficacy of using complete feed stuffs with different protein levels for rearing rainbow trout juvenile fish up to $10 \mathrm{~g}$. The purpose of the experiment was to establish the influence of different protein nutrition levels on trout productivity indices. For this purpose, five experimental groups of this year juvenile fish were formed by the method of analogues. The control group of fish consumed feed stuffs with the protein level of 52\%. During the comparative period, the experimental fish consumed feed of the control group. In the main period, the level of crude protein in trout feed stuffs ranged from 48 to $56 \%$ per $1 \mathrm{~kg}$. As a result of the study performed, it was found that the use of feed stuffs with high protein nutrition (56\%) in feeding of this year trout is accompanied by an increase in their weight by $12.3 \%(p<0.01)$ and their growth intensity - by $7.1-15.7 \%$, compared to the analogues who consumed feed with the protein level of $52 \%$. Reduction of this index to the level of $48 \%$ contributes to a probable reduction $(p<0.05)$ in weight by $11.5 \%$, and a decrease in growth intensity by 5.8-13.8\%. It has been proved that the cost of feed per $1 \mathrm{~kg}$ of weight gain in this year trout, which consumed feed stuff with a protein content of $56 \%$, was lower by $5.5 \%$, and with its content at $48 \%$ - by $7.4 \%$ higher, compared to fish that consumed feed stuff with the protein content of $52 \%$. At the same time, the safety of the experimental fish throughout the experiment was compliant with the normative indices in trout farming and was within the range of 75.2-78.1\%. The analysis of the obtained fish farming results showed that the most economically feasible is rearing of this year trout juvenile fish, who consume feed stuff with the protein nutritional value of $52 \%$, compared to a decrease or increase in this index to 48 and $56 \%$, respectively.
\end{abstract}

Keywords: rainbow trout, fish feeding, this year juvenile fish, compound feed stuffs, crude protein, productivity, economic efficiency. 


\section{Rationale of the article and analysis of recent research and publications.}

Modern research in the field of fish nutrition, taking into account their species, breed and age characteristics, along with the efficient use of protein feeds and supplements, aimed at solving the problem of providing the population of our planet with high quality food (FAO, 2016).

Adherence to optimal rearing conditions and well-balanced feeding are key factors that affect the intensity of fish growth and economic performance of the industry (Сгоров, 2011; СОУ 05.01.37-385:2006). Complete protein nutrition of trout is one of the most important factors that determines the efficiency of feed nutrients and the level of fish productivity at all stages of its cultivation (Щербина, 2006). Insufficient amount of protein in the diet can cause inhibition of fish growth and increase of feed consumption, while its excessive amount makes the diet unbalanced and can lead to additional feed consumption, excessive nitrogen release and water pollution (Шерман та ін., 2002; Jobling, 2016).

Some scientists believe that the growth and development of rainbow trout is significantly influenced by the level of crude protein in the feed stuff that it consumes (Cowey, 1992; Takeuchi et al., 1978). Other researchers claim that the productivity and quality of fish products are more influenced by the ratio and content of energy, protein and amino acids in the diet (Karabulut et al., 2010; Kim and Kaushik, 1992).

Thus, the study of different protein nutrition impact on rainbow trout this year juvenile fish in modern industrial conditions of cold-water fish farms of Ukraine is necessary and relevant.

\section{Materials and methods of the study.}

Experimental studies on this year juvenile rainbow trout Oncorhynchus mykiss (Walbaum, 1792) were carried out at "Shipot" farm, Perechyn district of Transcarpathian region.

The purpose of the scientific and economic experiment was to establish the influence of different protein nutrition levels on this year juvenile trout's productivity.

To do this, five experimental fish groups were formed by the method of analogues (table 1).

During the comparative period, the experimental fish consumed feed of the control group. In the main period, the

\section{Design of scientific and economic experiment}

\begin{tabular}{|c|c|c|c|c|}
\hline \multirow{3}{*}{ Groups of fish } & \multirow{3}{*}{$\begin{array}{l}\text { Fish-holding } \\
\text { density at the } \\
\text { beginning of } \\
\text { the experiment, } \\
\text { specimen } / \mathrm{m} 2\end{array}$} & \multirow{3}{*}{$\begin{array}{l}\text { Mean weight at } \\
\text { the beginning of } \\
\text { the experiment, } \Gamma\end{array}$} & \multicolumn{2}{|c|}{ Experimental periods } \\
\hline & & & $\begin{array}{c}\text { comparative (5 } \\
\text { days) }\end{array}$ & main (40 days) \\
\hline & & & \multicolumn{2}{|c|}{$\begin{array}{c}\text { crude protein content per } 1 \mathrm{~kg} \text { of } \\
\text { feed stuff, } \%\end{array}$} \\
\hline 1- control & 200 & $1.14 \pm 0.114$ & \multirow{5}{*}{52} & 52 \\
\hline 2- experimental & 200 & $1.14 \pm 0.102$ & & 48 \\
\hline 3- experimental & 200 & $1.12 \pm 0.095$ & & 50 \\
\hline 4- experimental & 200 & $1.15 \pm 0.107$ & & 54 \\
\hline 5- experimental & 200 & $1.11 \pm 0.088$ & & 56 \\
\hline
\end{tabular}


level of crude protein in the trout's feed of the experimental groups was regulated by replacing the individual components of the feed (using combined mathematical methods to optimize the calculation by means of AgroSoft WinOpti software). The nutritional value of the experimental feed stuffs is shown in table 2.

Feeding of this year juvenile rainbow trout was carried out 6 times a day, at regular intervals during the day. The required amount of feed was calculated according to the indices of juvenile fish individual weight and to the temperature of the environment at the time of feeding.

Holding density of the experimental fish at the beginning of the experiment was 200 specimens $/ \mathrm{m}^{2}$. Rearing of juvenile fish was carried out in ponds at the pond stage of $1 \mathrm{~m}$. The conditions of keeping this year juveniles during the experimental period complied with the generally accepted ones in trout farming (Инструкция..., 1985; COУ 05.01.-37-385:2006).

Test fishing of experimental trout was performed once every 5 days. 100 juvenile fish specimens of each group were subjected to electronic weigh- ing. The study results were processed by the method of variation statistics (Плохинский, 1969) using MS Excel and STATISTICA 7.0 software with built-in statistical functions.

\section{Results of the study and their discussion.}

It was found that in the main period of the experiment, due to different protein nutrition of this year juvenile trout, there were noticeable changes in the rates of their weight gain (table 3 ).

At the end of the experiment (45 days) the highest weight was reached by trout in groups 4and 5, who outweighed the control group analogues by 0.73 and $1.41 \mathrm{~g}$, respectively, or by 6.4 and $12.3 \%(\mathrm{p}<0.01)$. At the same time, this year juveniles in experimental groups 2 and 3 were inferior than the mentioned index of their control peers by 1.32 and $0.53 \mathrm{~g}$, respectively, or by $11.5(\mathrm{p}<0.05)$ and $4.6 \%$. The difference between the weight of fish of groups 2 and 5, which consumed feed with the protein content of 48 and $56 \%$,

\section{Content in $1 \mathrm{~kg}$ of compound feed, $\%$}

\begin{tabular}{|l|c|c|c|c|c|}
\hline \multirow{2}{*}{\multicolumn{1}{|c|}{ Index }} & \multicolumn{5}{c|}{ Groups of fish } \\
\cline { 2 - 6 } & 1st & 2nd & 3rd & 4th & 5 th \\
\hline Metabolic energy, MJ & 17.00 & 17.00 & 17.00 & 17.00 & 17.00 \\
\hline Crude protein & 52.00 & 48.00 & 50.00 & 54.00 & 56.00 \\
\hline Crude fat & 14.00 & 14.00 & 14.00 & 14.00 & 14.00 \\
\hline Crude fibre & 1.72 & 2.26 & 2.72 & 2.42 & 1.70 \\
\hline Calcium & 2.25 & 2.25 & 2.25 & 2.25 & 2.25 \\
\hline Total phosphorus & 1.50 & 1.50 & 1.50 & 1.50 & 1.50 \\
\hline Lysine & 3.00 & 3.00 & 3.00 & 3.00 & 3.00 \\
\hline Methionine & 1.00 & 1.00 & 1.00 & 1.00 & 1.00 \\
\hline Vitamin A, thousand IU & 15 & 15 & 15 & 15 & 15 \\
\hline Vitamin D3, thousand IU & 3.5 & 3.5 & 3.5 & 3.5 & 3.5 \\
\hline Vitamin E, mg & 250 & 250 & 250 & 250 & 250 \\
\hline
\end{tabular}




\section{Weight of experimental this year juvenile trout with different protein nutrition, $g$}

\begin{tabular}{|l|c|c|c|c|c|}
\hline \multirow{2}{*}{$\begin{array}{c}\text { Day of } \\
\text { experiment }\end{array}$} & \multicolumn{5}{|c|}{ Groups of fish } \\
\cline { 2 - 6 } & $1 \mathrm{st}$ & 2nd & 3rd & 4th & 5th \\
\hline 1 & $1.14 \pm 0.114$ & $1.14 \pm 0.102$ & $1.12 \pm 0.095$ & $1.15 \pm 0.107$ & $1.11 \pm 0.088$ \\
\hline 5 & $2.06 \pm 0.185$ & $2.03 \pm 0.140$ & $2.04 \pm 0.164$ & $2.03 \pm 0.155$ & $2.00 \pm 0.195$ \\
\hline 10 & $3.13 \pm 0.232$ & $3.17 \pm 0.201$ & $3.08 \pm 0.198$ & $3.12 \pm 0.249$ & $3.13 \pm 0.247$ \\
\hline 15 & $4.19 \pm 0.265$ & $4.12 \pm 0.208$ & $4.09 \pm 0.215$ & $4.27 \pm 0.201$ & $4.38 \pm 0.292$ \\
\hline 20 & $5.32 \pm 0.243$ & $5.01 \pm 0.243$ & $5.18 \pm 0.267$ & $5.56 \pm 0.282$ & $5.76 \pm 0.287$ \\
\hline 25 & $6.47 \pm 0.287$ & $5.99 \pm 0.284$ & $6.33 \pm 0.286$ & $6.93 \pm 0.257$ & $7.30 \pm 0.303^{*}$ \\
\hline 30 & $7.82 \pm 0.306$ & $7.12 \pm 0.212$ & $7.62 \pm 0.305$ & $8.38 \pm 0.289$ & $8.84 \pm 0.299^{*}$ \\
\hline 35 & $9.06 \pm 0.290$ & $8.14 \pm 0.245^{*}$ & $8.74 \pm 0.368$ & $9.66 \pm 0.356$ & $10.22 \pm 0.328^{* *}$ \\
\hline 40 & $10.27 \pm 0.323$ & $9.15 \pm 0.288^{*}$ & $9.80 \pm 0.367$ & $10.94 \pm 0.383$ & $11.58 \pm 0.385^{* *}$ \\
\hline 45 & $11.44 \pm 0.374$ & $10.12 \pm 0.313^{*}$ & $10.91 \pm 0.401$ & $12.17 \pm 0.425$ & $12.85 \pm 0.412^{* *}$ \\
\hline
\end{tabular}

$* \mathrm{p}<0.05 ; * * \mathrm{p}<0.01-$ compared to group 1.

respectively, in this period amounted to $27.0 \%$ in favor of the latter.

The description of this year juvenile trout's growth using mathematical methods confirmed the ascending shape of the growth curve (fig.).

This year juvenile trout's growth is described by a mathematical model with

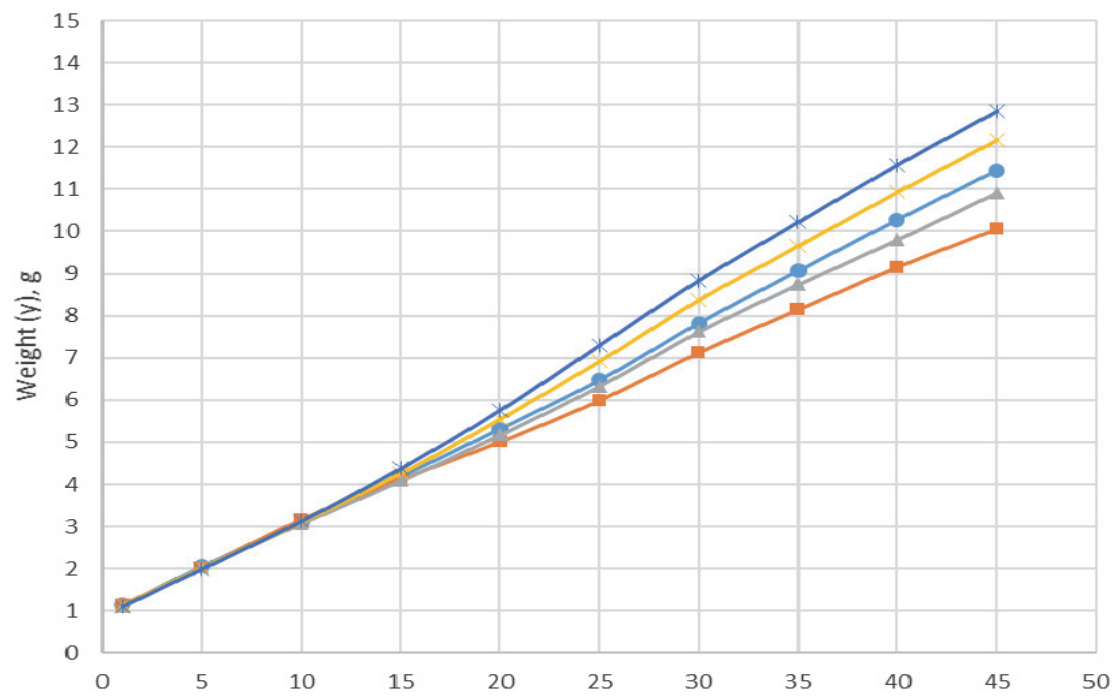

Experimental period (x), days

Fig. Graphic model of this year juvenile trout's growth with different protein nutrition. 
a nonlinear characteristics. By changing the experimental period (x), depending on the level of protein in the feed, one can predict the weight of this year juvenile trout (function - y): $\mathrm{CP})$ :

Group $1(52 \%$ of crude protein -

$$
\begin{gathered}
y=0.0005 x^{2}+0.211 x+0.9439 \\
\left(R^{2}=0.9997\right) ;
\end{gathered}
$$

Group $2(48 \% \mathrm{CP})$ :

$y=-0.0001 x^{2}+0.207 x+0.9923$

$$
\left(\mathrm{R}^{2}=0.9995\right)
$$

Group 3 (50 \% CP):

$$
\mathrm{y}=0.0002 \mathrm{x}^{2}+0.2126 \mathrm{x}+0.9138
$$$$
\left(\mathrm{R}^{2}=0.9996\right)
$$

Group 4 (54 \% CP):

$$
\mathrm{y}=0.0006 \mathrm{x}^{2}+0.2292 \mathrm{x}+0.8384
$$$$
\left(\mathrm{R}^{2}=0.9993\right)
$$

\section{Group $5(56 \% \mathrm{CP})$ :}

$$
\begin{gathered}
y=0.0006 x^{2}+0.2454 x+0.7317 \\
\left(R^{2}=0.9989\right) .
\end{gathered}
$$

The analysis of variance data show that different levels of protein nutrition consumed by this year juvenile trout highly reliably $(\mathrm{p}<0.001)$ affected the weight of the experimental fish. The share of this factor's influence was $84.8 \%$, which was by 5.6 times more than the influence of other factors.

According to the study results, during the period of this year juvenile trout rearing, the nature of changes in their weight mean daily gain depended on the level of protein in the feed and changes in the dynamics of weight accumulation (table 4). It was found that in almost all periods of the experiment, this year juveniles, who consumed feed with a higher content of crude protein, according to the mean daily gain outweighed the analogues, which were fed compound feed with lower protein nutrition.

It should be noted that in general, during the main period of the experiment, large mean daily weight gain was characteristic of this year juvenile trout in experimental groups 4 and 5, consuming feed with the protein content of 52 and $54 \%$, which by this index exceeded the controls, who consumed feed containing protein at the level of $50 \%$, respectively by 19 and $36 \mathrm{mg}$. Yearlings of trout in experimental groups 2 and 3 by the said index were inferior than the controls by 33 and $13 \mathrm{mg}$, respectively. The difference between the peers in groups 2 and 5 in the mean daily weight gain was $69 \mathrm{mg}$ for the main period of the experiment.

Analyzing the changes in fish weight depending on the quality of its feed at different stages of the experiment, it was found that feed costs per unit of weight gain were significantly lower in trout, which consumed feed with a higher content of digestible protein. In particular, specimens of group 5, who consumed food with the protein level of $56 \%$ had the mentioned index for the main period of the experiment at the level of $0.775 \mathrm{~kg}$, and outweighed the analogues of groups $1,2,3$ and 4 by $0.043,0.104,0.063$ and $0.02 \mathrm{~kg}$ respectively.

It should be noted that the survivability of experimental fish throughout the experiment was quite high, met the existing standards and ranged from 75.2 to $78.1 \%$.

Analyzing the efficiency indices of rearing this year juvenile trout, we can say that with different protein nutrition, they differed from each other (table 5). In particular, we can state the fact that the increase in protein nutrition of feed stuffs from 48 to $56 \%$ leads to an increase in ichtyomass of this year juveniles for the main period of the experiment by 7.0$43.1 \%$. As a result of the obtained data analysis on the consumption of feed by this year juveniles and their growth rate, it was found that the indices of feed consumption and its costs for the total increase in fish ichtyomass differed markedly among the groups. 


\section{Mean daily weight gain of this year juvenile trout with different energy nutrition, $g$}

\begin{tabular}{|l|c|c|c|c|c|}
\hline \multirow{2}{*}{\begin{tabular}{c}
\multirow{2}{*}{$\begin{array}{c}\text { Experimental } \\
\text { periods, days }\end{array}$} \\
\cline { 2 - 6 }
\end{tabular}} & 1st & 2nd & 3rd & 4th & 5th \\
\hline $1-5$ & 0.184 & 0.178 & 0.184 & 0.176 & 0.178 \\
\hline $6-10$ & 0.214 & 0.228 & 0.208 & 0.218 & 0.226 \\
\hline $11-15$ & 0.212 & 0.190 & 0.202 & 0.230 & 0.250 \\
\hline $16-20$ & 0.226 & 0.178 & 0.218 & 0.258 & 0.276 \\
\hline $21-25$ & 0.230 & 0.196 & 0.230 & 0.274 & 0.308 \\
\hline $26-30$ & 0.270 & 0.226 & 0.258 & 0.290 & 0.308 \\
\hline $31-35$ & 0.248 & 0.204 & 0.224 & 0.256 & 0.276 \\
\hline $36-40$ & 0.242 & 0.202 & 0.212 & 0.256 & 0.272 \\
\hline $41-45$ & 0.234 & 0.194 & 0.222 & 0.246 & 0.254 \\
\hline $\begin{array}{l}\text { Mean for the main } \\
\text { experimental } \\
\text { period (6-45 days) }\end{array}$ & 0.235 & 0.202 & 0.222 & 0.254 & 0.271 \\
\hline
\end{tabular}

These factors ultimately affected the the protein content of $52 \%$ (group 1). In prime cost of $1 \mathrm{~kg}$ ichthyomass gain of particular, according to the mentioned this year juvenile trout, which was the index, they outweighed analogues in all lowest in fish that consumed feed with other groups, respectively (according

\section{Economic efficiency of rearing this year juvenile trout with different energy nutrition}

\begin{tabular}{|l|c|c|c|c|c|}
\hline \multirow{2}{*}{ Index } & \multicolumn{5}{|c|}{ Groups of fish } \\
\cline { 2 - 6 } & $1 \mathrm{st}$ & 2 nd & 3rd & 4 th & 5th \\
\hline $\begin{array}{l}\text { Ichthyomass at the beginning of the main } \\
\text { experimental period, kg }\end{array}$ & 40.33 & 39.83 & 40.15 & 39.87 & 39.16 \\
\hline Survivability, \% & 77.6 & 75.2 & 76.9 & 78.1 & 77.8 \\
\hline Ichthyomass at theend of the experiment, kg & 177.55 & 152.2 & 167.8 & 190.1 & 199.95 \\
\hline $\begin{array}{l}\text { Ichthyomass gain for the main } \\
\text { experimental period, kg }\end{array}$ & 137.22 & 112.37 & 127.65 & 150.23 & 160.79 \\
\hline Feed costs per 1 kg of ichthyomass gain, kg & 0.818 & 0.879 & 0.838 & 0.795 & 0.775 \\
\hline $\begin{array}{l}\text { Feed costs for the total increase in } \\
\text { ichthyomass, kg }\end{array}$ & 112.25 & 98.77 & 106.97 & 119.43 & 124.61 \\
\hline $\begin{array}{l}\text { Production cost per 1 kg of compound } \\
\text { feed, UAH }\end{array}$ & 71.26 & 71.98 & 70.84 & 74.21 & 76.32 \\
\hline $\begin{array}{l}\text { Cost of feed stuff fed for the total increase } \\
\text { in ichthyomass, UAH }\end{array}$ & 7998.65 & 7109.70 & 7577.80 & 8863.11 & 9510.41 \\
\hline $\begin{array}{l}\text { Cost of feed spent per 1 kg of ichthyomass } \\
\text { gain, UAH }\end{array}$ & 58.29 & 63.27 & 59.36 & 59.00 & 59.15 \\
\hline Prime cost per 1 kg of ichthyomass gain, UAH & 83.27 & 90.39 & 84.81 & 84.28 & 84.50 \\
\hline
\end{tabular}

Note: measured in $2016 \mathrm{UAH}$. 
to the design of the experiment) by 8.5 , $1.8,1.2$ and $1.5 \%$.

Thus, in economic terms, when rearing this year juvenile trout to the mean weight of $10 \mathrm{~g}$, it is most appropriate to give them feed stuffs with the protein level of $52 \%$.

\section{Conclusions}

1. The use of feed stuffs with high protein content $(56 \%)$ in the feeding of these year juvenile trout is accompanied by their weight increase by $12.3 \%(\mathrm{p}<0.01)$ and growth intensity - by $7.1-15.7 \%$, compared to the analogues, consuming food with the protein level of $52 \%$. Reduction of this index to the level of $48 \%$ contributes to a probable decrease $(p<0.05)$ in weight by $11.5 \%$, and a decrease in growth intensity by $5.8-13.8 \%$.

2. It is proved that different levels of protein nutrition in this year juvenile trout significantly $(p<0.001)$ influenced the increase in the weight of experimental fish. The share of this factor's influence was $84.8 \%$, which is by 5.6 times more than the influence of other factors.

3. It was found that the cost of feed per $1 \mathrm{~kg}$ of weight gain in this year's juvenile trout, who received feed with the protein content of $56 \%$ was lower by $5.5 \%$, and with its content of $48 \%$ - by $7.4 \%$ higher compared to the fish that consumed feed with the protein content of $52 \%$. The survivability of the experimental fish throughout the entire experiment was almost similar and kept within the range of 75.2-78.1\%.

4. Analysis of the obtained results showed that the most economically feasible is rearing of this year ju- venile trout, using compound feeds with the nutritional protein value of $52 \%$, compared to a decrease or increase of this index to 48 and $56 \%$, respectively.

5. Prospects for further research are related to the study of the influence of different protein nutrition for this year juvenile rainbow trout weighing more than $10 \mathrm{~g}$ and marketable fish on the laws of its physiological, biochemical and morphological parameters.

\section{Список літератури}

1. Єгоров, Б. В. Фігурська, Л. В. Стан та перспективи розвитку форелівництва у рибоводних господарствах України. Зернові продукти і комбікорми. 2011. № 2. С. 37-39.

2. Инструкция по разведению радужной форели. Сост. Канидьев А. Н. Москва: ВНИИПРХ, 1985. 59 с.

3. Плохинский, Н. А. Руководство по биометрии для зоотехников. Москва: Колос, 1969. $246 \mathrm{c}$.

4. СОУ 05.01.-37-385:2006. Вода рибогосподарських підприємств. Загальні вимоги та норми. Київ: Міністерство аграрної політики України. 2006. 15 с.

5. Шерман, І. М., Гринжевський, М. В., Желтов, Ю. О., Пилипенко, Ю. В., Воліченко М. І. Наукове обгрунтування раціональної годівлі риб: Довідк.-навч. посіб. К.: Вища освіта, 2002. 126 с.

6. Щербина, М. А., Гамыгин, Е. А. Кормление рыб в пресноводной аквакультуре. М.: ВНИРО, 2006. 360 c.

7. Cowey, C. B. Nutrition: estimating requirements of rainbow trout. Aquaculture. 1992. № 100. P. 177-189.

8. Food and Agriculture Organization of the United Nations. El estado mundial de la pesca y la acuicultura. Contribución a la seguridad alimentaria y la nutrición para 
todos. 2016. Roma: Food and Agriculture Organization of the United Nations. p. 224.

9. Jobling, M. Fish nutrition research: Past, present and future. Aquaculture International. 2016. № 24. P. 767-786.

10. Karabulut, H. A., Yandi, I., Aras, N. M. Effects of different feed and temperature conditions on growth, meat yield, survival rate, feed conversion ratio and condition factor in rainbow trout (Oncorhynchus mykiss) fingerlings. Journal of Animal and Veterinary Advances. 2010. № 9(22). P. 2818-2823.

11. Kim, J. D., Kaushik, S. J. Contribution of digestible energy from carbohydrates and estimation of protein/energy requirements for growth of rainbow trout (Oncorhynchus mykiss). Aquaculture. 1992. № 106 (2). P. 161-169.

12. Takeuchi, T., Yokoyama, M., Watanabe, T., Ogino, C. Optimum Ratio of Dietary Energy to Protein for Rainbow. Trout Bulletin of the Japanese Society of Scientific Fisheries. 1978. № 44 (7). P. 729-732.

\section{References}

1. Yehorov, B. V., Fihurska L.V. (2011). Status and prospects of trout farming development in fish farms of Ukraine. Zernovi produkty i kombikormy. 2. 37-39.

2. Kanydev, A. N. (1985). Instruction on rearing rainbow trout. Moscow, Russia: VNYYPRKh. 59.

3. Plokhynskyi, N. A. (1969). Guidance on biometry for livestock experts. Moscow, Russia: Kolos. 246.

4. SOU 05.01.-37-385:2006. (2006). Water at fish-farms. General requirements and norms. Kyiv, Ukraine: Ministry of Agrarian Policy of Ukraine. 15.
5. Sherman, I. M., Hrynzhevskyi, M. V., Zheltov, Yu. O., Py`ly`penko Yu. V., Volichenko M. I. (2002). Scientific justification of balanced fish feeding: manual. Kyiv, Ukraine: Vyshcha osvita. 128.

6. Shcherbyna, M. A., Hamyhyn, E. A. (2006). Fish feeding in freshwater aquaculture. Moscow, Russia: VNYRO. 360.

7. Cowey, C. B. (1992). Nutrition: estimating requirements of rainbow trout. Aquaculture. 100. 177-189.

8. Food and Agriculture Organization of the United Nations. (2016). El estado mundial de la pesca y la acuicultura. Contribución a la seguridad alimentaria y la nutrición para todos. Roma: Food and Agriculture Organization of the United Nations. 224.

9. Jobling, M. (2016). Fish nutrition research: Past, present and future. Aquaculture International. 24. 767-786.

10. Karabulut, H. A., Yandi, I., Aras, N. M. (2010). Effects of different feed and temperature conditions on growth, meat yield, survival rate, feed conversion ratio and condition factor in rainbow trout (Oncorhynchus mykiss) fingerlings. Journal of Animal and Veterinary Advances. 9(22). 2818-2823.

11. Kim, J. D., Kaushik, S. J. (1992). Contribution of digestible energy from carbohydrates and estimation of protein/energy requirements for growth of rainbow trout (Oncorhynchus mykiss). Aquaculture. 106(2). 161-169.

12. Takeuchi, T., Yokoyama, M., Watanabe, T., Ogino, C. (1978). Optimum Ratio of Dietary Energy to Protein for Rainbow Trout. Bulletin of the Japanese Society of Scientific Fisheries. 44(7). 729-732.

\section{В. М. КОНӘратюК (2020). ВИРОЩУВАННЯ ЦЬОГОЛІТКІВ РАЙДУЖНОЇ ФОРЕЛІ ЗА РІЗНИХ РІВНІВ ПРОТЁ̈НУ У КОМБІКОРМАХ. АNIMAL SCIENCE AND FOOD TECHNOLOGY, 11(3): 34-42. https://doi.org/10.31548/animal2020.03.035.}


Анотація. У статті розглянуто питання ефективності використання повнораціонних комбікормів з різним рівнем протеїну за вирощування цьоголітків райдужної форелі до маси 10 г. Метою досліду було встановлення впливу різних рівнів протеїнового живлення форелі на показники їі продуктивності. Для цього за методом аналогів було сформовано п'ять піддослідних груп цьоголітків. Контрольна група риб отримувала комбікорми, рівень протеїну в яких становив 52 \%. У зрівняльний період піддослідна риба споживала комбікорм контрольної групи. В основний період рівень сирого протеїну в комбікормах форелі коливався від 48 до 56 \% у 1 кг. У результаті проведених досліджень встановлено, що використання у годівлі цьоголітків форелі комбікормів з підвищеною протеїновою поживністю (56 \%) супроводжується збільшенням їхньої маси на 12,3 \% (р<0,01) та інтенсивності росту - на 7,1-15,7\% у порівнянні з аналогами, що споживали корм із рівнем протеїну $52 \%$. зменшення цього показника до рівня 48 $\%$ сприяє вірогідному зменшенню $(p<0,05)$ маси на 11,5 \%, та зниженню інтенсивності росту на 5,8-13,8 \%. Доведено, що витрати корму на 1 кг приросту маси у цьоголітків форелі, які отримували комбікорми із вмістом протеїну на рівні $56 \%$, були меншими на 5,5 \%, а за його вмісту на рівні $48 \%$ - на 7,4 \% більшими у порівнянні з рибами, що споживали корм із вмістом протеїну на рівні 52 \%. Водночас збереженість піддослідних риб упродовж усього досліду відповідала нормативним показникам у форелівниитві й перебувала у межах 75,2-78,1. Аналізом отриманих рибницьких результатів встановлено, що найбільш економічно доцільним є вирощування цьоголітків форелі, які споживають комбікорм із поживністю 52 \% протеїну у порівнянні з зниженням чи підвищенням цього показника до 48 та 56 \% відповідно.

Ключові слова: райдужна форель, годівля риб, цьоголітки, комбікорми, сирий протеїн, продуктивність, економічна ефективність. 